\title{
Article \\ Temporal Recovery of Polymer-Coated Urea-N by Kentucky Bluegrass in the Field
}

\author{
Maxim J. Schlossberg
}

Citation: Schlossberg, M.J. Temporal Recovery of Polymer-Coated Urea-N by Kentucky Bluegrass in the Field. Horticulturae 2022, 8, 207. https:// doi.org/10.3390/

horticulturae 8030207

Academic Editor: Othmane Merah

Received: 31 December 2021

Accepted: 24 February 2022

Published: 26 February 2022

Publisher's Note: MDPI stays neutral with regard to jurisdictional claims in published maps and institutional affiliations.

Copyright: (c) 2022 by the author. Licensee MDPI, Basel, Switzerland. This article is an open access article distributed under the terms and conditions of the Creative Commons Attribution (CC BY) license (https:// creativecommons.org/licenses/by/ $4.0 /)$.
Department of Plant Science, The Pennsylvania State University, University Park, PA 16802, USA; mjs38@psu.edu; Tel.: +1-814-863-1015

\begin{abstract}
Relative to soluble N sources, controlled release fertilizer (CRF) fosters consistent turfgrass growth response and improved canopy quality while reducing $\mathrm{N}$ loss as nitrate, ammonia, and/or $\mathrm{N}_{2} \mathrm{O}$ from target systems. Commercial CRFs afford turfgrass managers greater operational efficiency and flexibility in nutrient management planning and compel the investigation of application rate thresholds to guide regional agencies tasked with their regulation. The experimental objective was to systematically evaluate, under an array of field conditions, Kentucky bluegrass (Poa pratensis L.) vigor/yield, fertilizer $\mathrm{N}$ offtake, canopy density, and canopy color temporal response to a single application of granular $\mathrm{N}$ fertilizer made at practical rates. In May of 2014 and 2015, plots within a mature Kentucky bluegrass system were fertilized by conventional urea or Duration 45 polymer coated urea (PCU) at a N rate of $43.9 \mathrm{~kg} \cdot \mathrm{ha}^{-1}\left(0.9 \mathrm{lbs} \mathrm{N} \cdot 1000 \mathrm{ft}^{-2}\right)$; or PCU (Duration 90, Duration 120, or $43 \% \mathrm{~N}$ Polyon) at a N rate of $87.8 \mathrm{~kg} \cdot \mathrm{ha}^{-1}\left(1.8 \mathrm{lbs} \mathrm{N} \cdot 1000 \mathrm{ft}^{-2}\right)$. Resulting measures of the described dependent variables proved similar over both growing seasons and were highly dependent on the $\mathrm{N}$ rate and PCU attribute. Following 18-week evaluations, the average total percent fertilizer $\mathrm{N}$ recoveries from conventional urea, Duration 45, Duration 90, Duration 120, and Polyon (43\% N) were $63 \%, 87 \%, 82 \%, 78 \%$, and $77 \%$, respectively. Temporal release among commercial PCU fertilizers indicates varying suitability by commodity and seasonal nutrient requirements. Hypothesis tests on experiment-end unaccounted fertilizer $\mathrm{N}$ totals show one $87.8 \mathrm{~kg} \mathrm{~N} \cdot \mathrm{ha}^{-1}$ application of the described $100 \%$ PCU fertilizer treatments poses no greater environmental risk than a $43.9 \mathrm{~kg} \mathrm{~N} \cdot \mathrm{ha}^{-1}$ application of conventional urea fertilizer.
\end{abstract}

Keywords: controlled-release; fertilizer; nutrient fate; plant nutrition; turfgrass

\section{Introduction}

Of the several mechanisms shown to impart slow- or controlled-release of nutrients from fertilizer, physical coating of water-soluble $\mathrm{N}$ sources has proven an increasingly dependable and effective one [1,2]. Sulfur-coated urea (SCU) comprises the original massproduced controlled-release $\mathrm{N}$ fertilizer; by which plant-availability of urea-N is initiated only by physical rupture or 'failure' of the sulfur coating [3].

The prolific marriage of sulfur and urea was hardly a proverbial crapshoot, given sulfur's established role as a secondary plant nutrient, fungicide, and additive mitigating the caking tendency of many fertilizers [4]. Moreover, elemental sulfur comprises a biodegradable and inexpensive accident that facilitates plant recovery of urea-N in neutral to alkaline soil [5]. Relative to granular urea, and presuming the integrity of the coating is maintained through application, SCU significantly improves fertilizer $\mathrm{N}$ recovery by treated turfgrass [6].

This is likely why the next generation of coated fertilizer built upon, rather than replaced, the sulfur component. While the controlled release of urea N from SCU is governed by the sulfur-coat thickness, the addition of a thin thermoplastic or resin envelope around the SCU prill improved the coating integrity without further $\mathrm{N}$ dilution [7]. 
These polymer-sulfur-coated urea (PSCU) or polymer-coated/sulfur-coated urea (PC/SCU) hybrids featured a more linear release rate than SCU and were widely adopted [8]. Unbeknownst to many, alkyd resin-coated urea fertilizers predated SCU mass distribution [2]. Yet it was not until the 21st century that the specialty fertilizer marketplace heralded granules coated only by a thin layer of polyurethane or polyolefin as the preferred technology $[9,10]$. Owing to their thinner coat, polymer-coated fertilizers typically possess a higher grade than their sulfur coated counterparts [8]. Polymer-coated urea (PCU) is minimally affected by microbial activity and extensively used in the turf, landscaping, and horticulture industries [1].

While polymers proved aptly supportive of the original, impermeable coating mechanism, this application also marked the advent of semi-permeable coatings [11,12]. In contrast to the physical rupture or coating 'failure' release mechanism already described in first- and second-generation coated fertilizers, semi-permeable coatings facilitate a multistage diffusion release mechanism governed by water transfer $[13,14]$.

This semi-permeable coating release mechanism comprises an osmotically-driven nutrient transfer from the fertilizer-polymer interface to the polymer-soil interface in the following sequence; (i) diffusion/swelling; (ii) degradation of the polymer coating, and (iii) fracture or dissolution $[15,16]$. Controlling factors include the coating thickness, soil temperature, soil moisture, and soil $\mathrm{N}$ concentration gradient, ideally falling in synchrony with vegetative growth and plant nutrient requirements [17].

Relative to soluble N sources, research reveals application of controlled release fertilizer (CRF) supports stabilized turfgrass growth response and improved canopy quality while reducing $\mathrm{N}$ loss as nitrate [18,19], ammonia [20,21], and $\mathrm{N}_{2} \mathrm{O}[22-25]$ from turfgrass systems [26,27].

The environmental and economic sustainability of professional turfgrass management rely heavily on operational efficiency. Thus, stakeholders maintain a keen interest in realizing cost benefits from technology supporting extended nutrient availability following a single, yet sizable, fertilizer application to turfgrass systems either late or early in the growing season [28].

Many states in the Mid-Atlantic region of the USA (MD, NJ, NY, and VA) have enacted fertilizer guidelines or currently regulate fertilization of turfgrass areas. Among other things, such regulations typically limit the rate of fertilizer nitrogen $(\mathrm{N})$ on either a per month or per application basis. Turfgrass fertilizer legislation currently pending in the Commonwealth of Pennsylvania (PA SB 251) affords provisional exceedance of application rate limits for dependable controlled-release fertilizer technologies [29].

Given the widespread reliance on annual or semi-annual application of controlledrelease $\mathrm{N}$ fertilizers by our stakeholders, research is needed to develop specific fertilizer guidance for effective utilization. The consequences of not populating the Pennsylvania Bulletin with acceptable rates of evaluated controlled-release $\mathrm{N}$ fertilizers include increased visitations by lawn care fertilizer applicators and risk of $\mathrm{NH}_{3}$ volatilization and/or surface runoff resulting from more frequent application of granular urea-N. Ammonia $\left(\mathrm{NH}_{3}\right)$ emissions deteriorate air quality and contribute non-point N-loads to surface water [30-36].

Many turfgrass managers desire results from applied, replicated agronomic research conducted by Land-grant University personnel. Furthermore, direct measurement of turfgrass growth (clipping yield) and total leaf nitrogen content, from treated and control plots, facilitates quantitative assessment of fertilizer $\mathrm{N}$ offtake and percent recovery for development of responsible application rate thresholds by regional agencies. Our experimental objective was to systematically evaluate, under an array of field conditions, the Kentucky bluegrass vigor/yield, fertilizer $\mathrm{N}$ offtake, canopy density, and canopy color temporal response following single applications of conventional or polymer-coated granular urea-N fertilizers at practical rates. 


\section{Materials and Methods}

A Hagerstown silt loam (fine, mixed, semiactive, mesic Typic Hapludalfs) was established to Kentucky bluegrass (Poa pratensis L. 'Midnight') sod in 2012 and subsequently maintained within the J. Valentine Turfgrass Research Center (University Park, PA, USA). From April to May 2014, plots were mowed every $7 \pm 3$ days at a 3-cm height of cut, and clippings were removed. Analysis of soil collected from the upper 15-cm of the profile in April 2014 indicated a neutral soil $\mathrm{pH}$ and limited availability of soil nitrate and/or ammonium. In late April, a maintenance granular fertilizer application delivered $30 \mathrm{~kg} \mathrm{Mg}$, $60 \mathrm{~kg} \mathrm{~S}$, and $50 \mathrm{~kg} \mathrm{~K} \cdot \mathrm{ha}^{-1}$.

Beginning in May, the experimental area was mowed twice each week at a $3-\mathrm{cm}$ height of cut using a dedicated 56-cm rotary deck-mower (JS60, John Deere Inc., Moline, IL, USA) with 'factory' bagger (clippings removed). Following the described mowing on 13 May, a randomized complete block design was installed. All 183- $\times 122-\mathrm{cm}$ plots in the five (5) replicate blocks were separated by a minimum 15- or 61-cm distance on their respective long or short boundary.

Granular urea-based N fertilizers (Table 1) were applied to randomly-selected plots at a $\mathrm{N}$ rate of 43.9 or $87.8 \mathrm{~kg} \cdot \mathrm{ha}^{-1}\left(0.9\right.$ or $\left.1.8 \mathrm{lbs} \mathrm{N} \cdot 1000 \mathrm{ft}^{-2}\right)$. An unfertilized control plot $(0 \mathrm{~kg} \mathrm{~N})$ was maintained in each block. Pre-weighed, half-plot rates of each fertilizer were prepared in ten HDPE snap vials, and the contents were uniformly distributed one at a time over each half-plot using a 91.5- $\times 122-\mathrm{cm}$ plywood 'randomizer' frame [37]. Following application of all fertilizer treatments, the experimental area was flagged to prevent inadvertent mowing by facility personnel. Later that day (13 May), the Experiment 1 granular fertilizer applications were activated by an approximate $1-\mathrm{cm}$ precipitation event.

Table 1. Descriptions of urea-based nitrogen fertilizer products evaluated in the field study.

\begin{tabular}{|c|c|c|c|c|}
\hline \multicolumn{2}{|c|}{$\begin{array}{c}\text { Nitrogen }(\mathrm{N}) \text { Fertilizer } \\
\text { Treatment }\end{array}$} & \multirow{2}{*}{$\begin{array}{l}\text { Rate } \\
\mathrm{ha}^{-1}\end{array}$} & \multirow{2}{*}{$\begin{array}{l}\text { Component(s) } \\
\text { Description, \% } \\
\text { Inclusion }\end{array}$} & \multirow[t]{2}{*}{ Manufacturer } \\
\hline Name & Grade & & & \\
\hline Urea & $46-0-0$ & $43.9 \mathrm{~kg} \mathrm{~N}$ & $\begin{array}{c}100 \% \text { water soluble } \\
\text { urea-N }\end{array}$ & $\begin{array}{c}\text { Alfa-Aesar, Ward Hill, } \\
\text { MA, USA }\end{array}$ \\
\hline Duration 45 & $44-0-0$ & $43.9 \mathrm{~kg} \mathrm{~N}$ & \multirow{4}{*}{$\begin{array}{c}100 \% \text { polymer-coated } \\
\text { controlled release } \\
\text { urea-N }\end{array}$} & \\
\hline Duration 90 & $44-0-0$ & $87.8 \mathrm{~kg} \mathrm{~N}$ & & Wichita, KS, USA \\
\hline Duration 120 & $43-0-0$ & $87.8 \mathrm{~kg} \mathrm{~N}$ & & 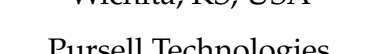 \\
\hline Polyon & $43-0-0$ & $87.8 \mathrm{~kg} \mathrm{~N}$ & & Sylacauga, AL, USA \\
\hline
\end{tabular}

A fabricated chute and 'micro-bagger' was installed on the 56-cm rotary mower (3-cm height of cut) to collect clipping yields from the centers of each plot on 20 and 27 May (7 and 14 days after treatment, DAT); 4, 10, 17, and 26 June (22, 28, 35, and 44 DAT); 4, 11, 20, and 29 July $(52,59,68$, and 77 DAT); 8, 17, and 27 August (87, 96, and 106 DAT); and 3, 10, and 17 September 2014 (113, 120, and 127 DAT). Once collected, the micro-bagger was replaced with the factory bagger, and all remaining turf was mowed (clippings removed). The plots remained flagged continuously and were not otherwise mowed.

Clippings were dried to constant mass in a forced-air oven (65 C) and transferred to desiccators to cool. The mass of dry clipping samples was determined at 1-mg resolution and recorded. For every plot, a 0.5-g clipping subsample of the first and second yields, third and fourth yields, and ultimately 15th and 16th yields; were pooled and ground to pass a $0.5-\mathrm{mm}$ sieve, and then analyzed for total nitrogen by medium temperature furnace combustion (EA-1110 CHNS analyzer, CE Instruments, Milan, Italy).

Thus, $\mathrm{N}$ offtake $\left(\mathrm{kg} \mathrm{N} \cdot \mathrm{ha}^{-1}\right)$ was calculated as the product of each yield collection and its pooled tissue $\mathrm{N}$ (equal to the earlier or later collected date) on a per-plot basis. Nitrogen offtake represents the apparent $\mathrm{N}$ recovery over the time period from the last mowing event, either 0 DAT or more recent clipping yield collection. Fertilizer $\mathrm{N}$ offtake 
$\left(\mathrm{kg} \mathrm{FN} \cdot \mathrm{ha}^{-1}\right)$ for each plot and date was calculated by subtracting control plot offtake on a per block basis [38].

Negative fertilizer $\mathrm{N}$ offtake values were replaced with zeroes before statistical analysis. Percent fertilizer $\mathrm{N}$ recovery (\%FNR) was calculated as the quotient of cumulative fertilizer $\mathrm{N}$ offtake by the original 43.9 or $87.8 \mathrm{~kg} \mathrm{~N} \cdot \mathrm{ha}^{-1}$ fertilizer application [21]. In May 2015, the experimental area was mowed twice each week as described. Following the 19 May mowing, a randomized complete block design of $183-\times 122-\mathrm{cm}$ plots in five (5) replicate blocks, separated by 15- or 61-cm on their respective long or short boundary, was installed in a unique location adjacent to that of the 2014 Experiment 1 location.

On 19 May 2015, Experiment 2 was initiated by applying granular urea-based N fertilizers (Table 1) to randomly-selected plots at a $\mathrm{N}$ rate of $43.9 \mathrm{or} 87.8 \mathrm{~kg} \cdot \mathrm{ha}^{-1}$, as previously described. An unfertilized control plot $(0 \mathrm{~kg} \mathrm{~N})$ was maintained in each block.

On 20 May 2015, the urea, Duration 90, and Polyon (43-0-0) granular urea-based N fertilizer treatments (Table 1) were applied, as described one day previous, to $183-\times 122-\mathrm{cm}$ plots in five additional blocks on a further-adjacent area of Kentucky bluegrass. This independent study comprises Experiment 3, with an unfertilized control plot maintained in each block. The following day, a rotary spreader was used to broadcast $28 \mathrm{~kg} \mathrm{~K} \cdot \mathrm{ha}^{-1}$ as granular muriate of potash $(\mathrm{KCl})$ to all plots and borders of Experiments 2 and 3. The plots were then irrigated by approximately $1 \mathrm{~cm}$ of potable $\mathrm{H}_{2} \mathrm{O}$.

A passive multi-spectral radiometer (CropScan MSR87, Rochester, MN, USA) was used to measure percent canopy reflectance, relative to simultaneous visible and near infrared irradiance, in the 460, 560, 660, and $810 \pm 5$-nm wavebands. Operation of the radiometer required cloudless conditions and orientation of its downward-facing sensors perpendicular to the plot surface at a $0.7-\mathrm{m}$ height, providing for a $0.1-\mathrm{m}^{2}$ circular sample area. On days conditions permitted, two rounds of percent reflectance measures were made in the \pm 3 -h interval around solar noon. The mean of duplicate 460-, 560-, and 660-nm reflectance percentages per plot were used to calculate the dark green color index (DGCI) per [39]. Mean percent reflectance in the 810- and 660-nm wavebands were used to calculate the normalized differential vegetative index (NDVI) per [40]. These DGCI and NDVI indices provide dependably reproducible measures of turfgrass canopy dark green color and density, respectively [41].

Clipping yields were collected from the centers of plots initially fertilized 19 May on 27 May 2015 (8 DAT); 3, 10, 18, and 26 June (15, 22, 30, and 38 DAT); 3, 10, 17, and 25 July $(45,52,59$, and 67 DAT); 2, 11, 18, and 26 August (75, 84, 91, and 99 DAT); and 4, 15, and 29 September $2015(108,119$, and 133 DAT). Yields from the centers of plots initially fertilized 20 May 2015 (last five blocks) were collected 28 May (8 DAT); 3, 10, 18, and 25 June (14, 21, 29, and 36 DAT); and 3, 10, 17, and 26 July (44, 51, 58, and 67 DAT).

Per terms of the associated Experiment 3 research protocol, urea treated plots initially fertilized 20 May received a $43.9 \mathrm{~kg} \mathrm{~N} \cdot \mathrm{ha}^{-1}$ retreatment on 27 July 2015. Thus, combined analysis precluded observations from the urea treated plots after 27 July (input cells treated as missing data). However, comprehensive data collection continued on plots treated 20 May 2015 using Ctd U2 (Duration 90) or Ctd U4 (Polyon). Specifically, clipping yields were collected on 2, 11, 18, and 26 August (74, 83, 90, and 98 DAT); and 4, 16, and 30 September $2015(107,119$, and 133 DAT). As described, the micro-bagger was replaced with the factory bagger following clipping yield collections, and all remaining turf was mowed (clippings removed). For the 2015 Experiments 2 and 3, N offtake $\left(\mathrm{kg} \mathrm{N} \cdot \mathrm{ha}^{-1}\right)$ was calculated as the product of each yield collection and its pooled tissue $\mathrm{N}$ (equal to the earlier or later collected date) on a per-plot basis for only the first six clipping yield collections. From 10 July to 30 September 2015, a subsample of each yield collection was individually analyzed for total $\mathrm{N}$ and used to calculate $\mathrm{N}$ offtake on a per-plot basis as described.

Data from all three experiments featuring repeated measures of turfgrass clipping yield, $\mathrm{N}$ offtake, canopy quality indices, and percent fertilizer $\mathrm{N}$ recovery were combined for analysis using the MIXED procedure (SAS Institute, v. 9.4, Cary, NC, USA). The employment of identical treatment levels and similar cultural, climatic, and edaphic conditions 
compelled the designation of 'experiment (EXP),' and all subsequent interaction terms, as random variables. Significance of N-fertilizer treatment (TRT) or time (DAT) effect was F-tested by its specific EXP interaction term [42].

Time-series covariate structures, selected using best fit criteria, facilitated F-testing of the TRT $\times$ DAT interaction by the TRT $\times$ DAT $\times$ EXP error term. Likewise, monthly mean percent fertilizer $\mathrm{N}$ recoveries were calculated on a per-plot basis and modeled by the main effects and interaction of fertilizer and month after treatment (MAT) as described. Careful inspection of diagnostic plots confirmed abidance of a normal error distribution, constant variance, and independent errors assumptions for all dependent variables.

Main and interaction effect hypothesis tests employed two-tailed separation of treatment means by Fisher's protected least significant difference (LSD) at a 0.05-alpha level. Excluding Experiment 3 data, four 'equal unaccounted fertilizer $\mathrm{N}$ as $\mathrm{kg} \cdot \mathrm{ha}^{-1}$ ' pairedsample t-tests on sample sets $(n=10)$ of within-block unaccounted $\mathrm{N}$ differences between conventional urea and PCU treatment were conducted using the UNIVARIATE procedure (SAS Institute, v. 9.4, Cary, NC, USA). Additionally, three paired sample t-tests were run to compare unaccounted fertilizer $\mathrm{N}$ from the Ctd U1 treatment versus the Ctd U2, U3, and U4 fertilizer treatments.

\section{Results}

Regional weather conditions during the 2014 growing season were warm and humid. July was the warmest month of 2014 with a $22.7 \mathrm{C}$ mean temperature and the most daily high temperatures exceeding $32 \mathrm{C}(n=8)$. The monthly mean, low, and high temperatures for June or August were similar and within one degree centigrade of 21, 15, and 27.5 C, respectively. September was significantly cooler than June or August but warmer than May.

Regional weather conditions over the 2015 growing season were consistent. May was dry and warm (18.2 C mean temperature). June and the first half of July were wet and mild, but the second half of July warmed enough to raise its monthly mean temperature to $21.7 \mathrm{C}$. Monthly mean temperatures for June and August were 20 and 20.6 C, respectively. More high temperatures $>32 \mathrm{C}(n=4)$ were observed in the first ten days of September (mean temperature of $18.5 \mathrm{C}$ ) than any previous month in 2015.

\subsection{Clipping Yield}

The mean clipping yield was significantly influenced by the main effect of treatment (Table 2). These and other main effect means are briefly discussed regardless of accompanying significant interaction with the fixed DAT effect as justification for such summary variable emphasis following single field trials is well documented [43-46]. Videlicet, dependence of biological systems on accumulation of temperature conditions (i.e., heat units), in tandem with an intrinsically random distribution of weather conditions, precludes such capture over two growing seasons. Obliging the broad inference space affords the reader a mean outcome expected under similar conditions over an 18-week period following the described fertilizer application(s) (Table 2). 
Table 2. ANOVA of Kentucky bluegrass clipping yield, fertilizer $\mathrm{N}$ offtake, and canopy vegetative indices by source, and main effect (pooled) means by treatment level.

\begin{tabular}{|c|c|c|c|c|c|c|c|c|c|c|}
\hline \multirow{2}{*}{ Source } & \multicolumn{2}{|l|}{ df } & \multirow{2}{*}{$\begin{array}{l}\text { Clipping } \\
\text { Yield }\end{array}$} & \multicolumn{2}{|c|}{ df } & \multirow{2}{*}{$\begin{array}{c}\text { Fertilizer N } \\
\text { Offtake }\end{array}$} & \multicolumn{2}{|c|}{ df } & \multicolumn{2}{|c|}{ Canopy } \\
\hline & Num & Den & & Num & Den & & Num & Den & DGCI & NDVI \\
\hline & & & $p$ value & & & $p$ value & & & \multicolumn{2}{|c|}{$p$ value } \\
\hline Treatment (TRT) & 5 & 8 & $<0.001$ & 4 & 6 & $<0.001$ & 5 & 8 & 0.001 & 0.002 \\
\hline Days after TRT (DAT) & 15 & 30 & ns & 15 & 30 & $<0.001$ & 10 & 20 & 0.006 & 0.004 \\
\hline $\mathrm{TRT} \times \mathrm{DAT}$ & 75 & 113 & $<0.001$ & 60 & 83 & $<0.001$ & 50 & 76 & 0.001 & 0.001 \\
\hline Fertilizer & $\mathrm{kg} \mathrm{N} \cdot \mathrm{ha}^{-1}$ & & Mean, $\mathrm{kg} \cdot \mathrm{ha}^{-1}$ & \multicolumn{5}{|c|}{ Mean, $\mathrm{kg} \cdot \mathrm{ha}^{-1}$} & \multicolumn{2}{|c|}{ Mean, index } \\
\hline Control & 0 & & 111 & & & - & & & 0.664 & 0.879 \\
\hline Urea, U & 43.9 & & 146 & & & 1.74 & & & 0.674 & 0.889 \\
\hline Ctd U1, Dur45 & 43.9 & & 163 & & & 2.43 & & & 0.678 & 0.890 \\
\hline Ctd U2, Dur90 & 87.8 & & 207 & & & 4.50 & & & 0.684 & 0.894 \\
\hline Ctd U3, Dur120 & 87.8 & & 201 & & & 4.28 & & & 0.690 & 0.899 \\
\hline Ctd U4, Polyon & 87.8 & & 198 & & & 4.23 & & & 0.688 & 0.897 \\
\hline $\mathrm{LSD}_{5 \%}$ & & & 15 & & & 0.51 & & & 0.007 & 0.008 \\
\hline
\end{tabular}

All fertilizer treatments fostered a greater mean clipping yield than the control, thus, confirming the $\mathrm{N}$-limited status of the Kentucky bluegrass system over the two growing seasons. The Duration 45 coated fertilizer treatment supported a significantly greater mean clipping yield than conventional urea, despite both having been applied at a $43.9 \mathrm{~kg} \mathrm{~N} \cdot \mathrm{ha}^{-1}$ (Table 2). All coated fertilizer treatments applied at the $87.8 \mathrm{~kg} \cdot \mathrm{ha}^{-1} \mathrm{~N}$ rate showed similar mean clipping yields and significantly exceeded that of conventional urea or Duration 45 applied at $43.9 \mathrm{~kg} \mathrm{~N} \cdot \mathrm{ha}^{-1}$ (Table 2).

The clipping yield was influenced by an interaction between fertilizer treatment and sample DAT (Table 2). From 14 to 45 DAT, yields collected from the unfertilized control plots comprised the sole constituent of the lowest statistical grouping (Figure 1). This is not unexpected, given Kentucky bluegrass has a monthly N requirement of 20 to $40 \mathrm{~kg} \cdot \mathrm{ha}^{-1}$ [1] The clipping yield response to the urea treatment was notably elevated in the $21 \mathrm{DAT}$, yet promptly declined from 25 to 45 DAT (Figure 1). From 50 to 130 DAT, clipping yield from the urea treatment was statistically similar to that of unfertilized plots.

By 21 DAT, the Duration 45 and Duration 90 coated fertilizer treatments showed similar growth rate to the urea treatment. Yet the semi-permeable release mechanism of Duration 45 supported significantly greater clipping yield than the urea treatment from 35 to 55 DAT (Figure 1). However, the yield response to Duration 45 treatment was surpassed by that of Duration 90 by 28 DAT, and by Duration 90 or 120 treatment by 35 DAT. The yield response of Kentucky bluegrass to the Polyon treatment was limited from 0 to 35 DAT (Figure 1). By $44 \mathrm{DAT}$, the yield response to coated fertilizer treatments applied at the $87.8 \mathrm{~kg} \cdot \mathrm{ha}^{-1} \mathrm{~N}$ rate significantly exceeded that of treatments applied at the $43.9 \mathrm{~kg} \cdot \mathrm{ha}^{-1} \mathrm{~N}$ rate, and that trend continued to approximately 90 DAT.

A statistically similar Kentucky bluegrass growth rate, resulting from equivalent urea or Duration 45 fertilization, was observed from 90 to 130 DAT. Growth response to Duration 90 remained intermediate to the $43.9 \mathrm{~kg} \cdot \mathrm{ha}^{-1} \mathrm{~N}$ treatments and the $87.8 \mathrm{~kg} \cdot \mathrm{ha}^{-1}$ $\mathrm{N}$ treatments supplied by Duration 120 and Polyon coated fertilizers from 90 to 115 DAT (Figure 1). From 90 to 130 DAT, yield response to Duration 120 and Polyon treatments comprised the highest statistical grouping (Figure 1).

Likewise, the Duration 120 and Polyon fertilizer treatments showed the most consistent growth rate over the 18-week experimental period. This is not surprising, given the $87.8 \mathrm{~kg} \cdot \mathrm{ha}^{-1} \mathrm{~N}$ dose supplied by these fertilizer treatments had the potential to satisfy the minimal monthly $\mathrm{N}$ requirement of Kentucky bluegrass; i.e., $20 \mathrm{~kg} \cdot \mathrm{ha}^{-1}$, over the experimental duration. Of course, the Duration 90 fertilizer treatment could have as well but released too great an N fraction stimulating shoot growth 25 to 90 DAT (Figure 1). 

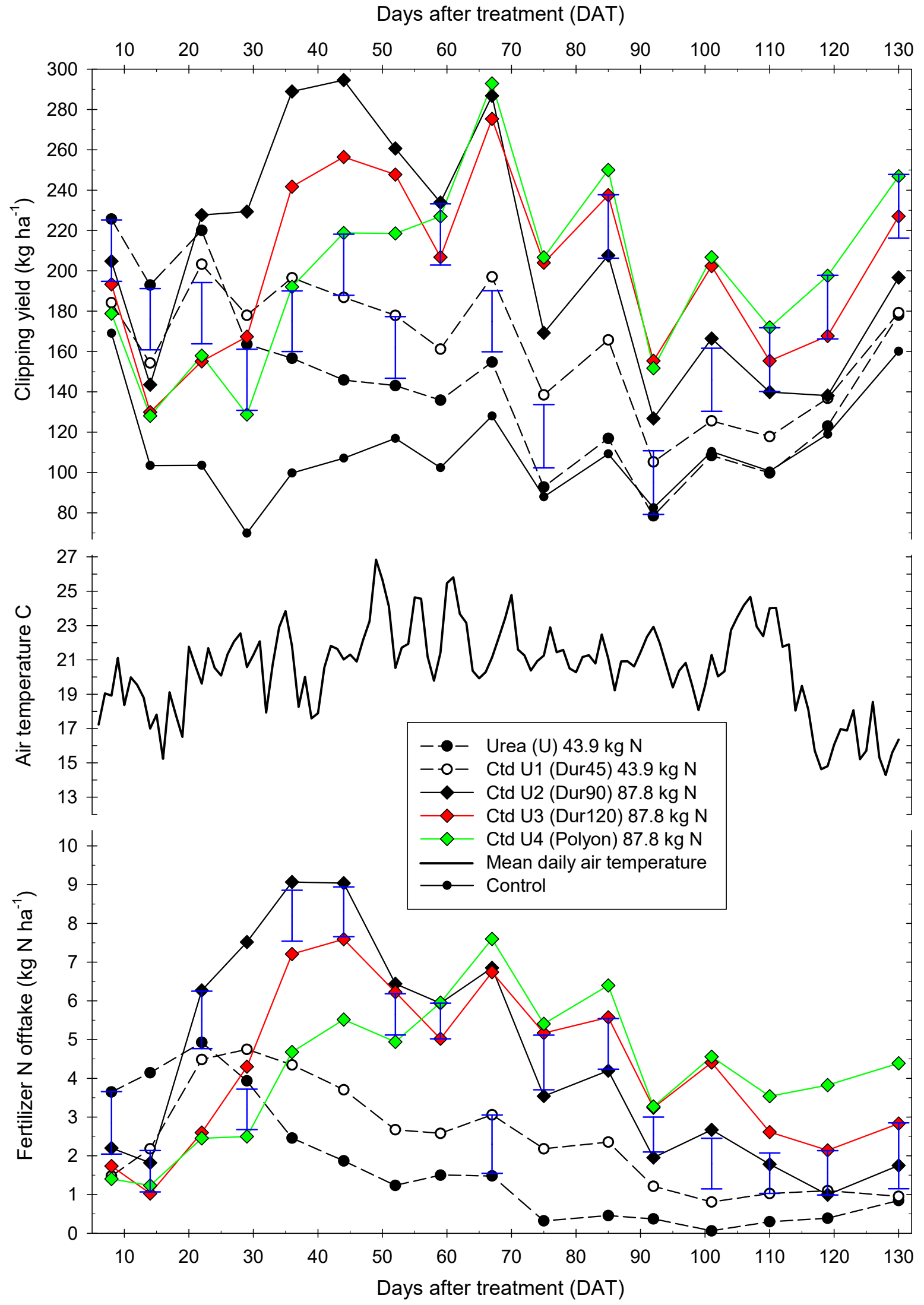

Figure 1. Kentucky bluegrass clipping yield and fertilizer $\mathrm{N}$ offtake $\left(\mathrm{ha}^{-1}\right)$ by fertilizer treatment and mean daily air temperature, all by days after treatment (DAT). Blue error bar lengths denote Fisher's Protected Least Significant Difference (LSD) at a 0.05 alpha level. 


\subsection{Fertilizer N Offtake}

Fertilizer $\mathrm{N}$ offtake was significantly influenced by the main effect of treatment (Table 2). As with clipping yield, the Duration 45 coated fertilizer treatment supported significantly greater mean fertilizer $\mathrm{N}$ offtake than conventional urea (Table 2). The mean cumulative fertilizer $\mathrm{N}$ offtake, pooled over the three experiments, was 27.9 or $38.9 \mathrm{~kg} \cdot \mathrm{ha}^{-1}$ for the conventional urea or Ctd U1 treatment, respectively. All coated fertilizer treatments applied at the $87.8 \mathrm{~kg} \cdot \mathrm{ha}^{-1} \mathrm{~N}$ rate showed similar mean fertilizer $\mathrm{N}$ offtake significantly exceeding that of conventional urea or Duration 45 (Table 2). The mean cumulative fertilizer $\mathrm{N}$ offtake from plots treated by the Ctd U2, Ctd U3, or Ctd U4 treatment was 72.0, 68.4, or $67.7 \mathrm{~kg} \cdot \mathrm{ha}^{-1}$, respectively.

Considering plant available $\mathrm{N}$ highly influences shoot growth under optimal environmental conditions, a similar interacting influence of fertilizer treatment and sample DAT on fertilizer $\mathrm{N}$ offtake response was not unexpected (Figure 1). Fertilizer $\mathrm{N}$ offtake resulting from the described conventional urea treatment resided within the highest statistical grouping 8, 14, and 22 DAT.

Due to a fraction of its prills having a semi-permeable coating, the Ctd U1 (Duration 45) fertilizer $\mathrm{N}$ offtake was significantly less than that of urea treatment 8 and $14 \mathrm{DAT}$. The two fertilizer treatments showed statistically equivalent fertilizer $\mathrm{N}$ offtake 22 and 29 DAT, and again 67 DAT (Figure 1). Yet from 36 to 59 and 75 to 85 DAT, significantly more fertilizer $\mathrm{N}$ was recovered in clippings of plots treated by the Ctd U1 than the urea treatment. From 92 to $130 \mathrm{DAT}$, mean fertilizer $\mathrm{N}$ offtake resulting from the $43.9 \mathrm{~kg} / \mathrm{ha} \mathrm{N}$ treatments were statistically equal (Figure 1 ).

From 22 to $67 \mathrm{DAT}$, fertilizer $\mathrm{N}$ offtake recovered in clippings treated by the Ctd U2 (Duration 90) treatment resided within the highest statistical grouping (Figure 1). From the 29 to 130 DAT clipping collection, neither $43.9 \mathrm{~kg} \cdot \mathrm{ha}^{-1} \mathrm{~N}$ fertilizer treatment supported an offtake rate within the highest statistical grouping (Figure 1). The highest mean fertilizer $\mathrm{N}$ offtake rates over the experimental period resulted from the $87.8 \mathrm{~kg} \mathrm{~N} \cdot \mathrm{ha}^{-1} \mathrm{Ctd} \mathrm{U} 2$ (Duration 90) fertilizer and were observed 36 to 44 DAT (latter half of June).

These $>9.0 \mathrm{~kg} \cdot \mathrm{ha}^{-1} \mathrm{~N}$ offtakes equated to a mean daily fertilizer $\mathrm{N}$ offtake of $1.2 \mathrm{~kg} \cdot \mathrm{ha}^{-1}$ $\left(0.025 \mathrm{lbs} \mathrm{N} \cdot 1000 \mathrm{ft}^{-2}\right)$. The mean air temperature over the 29 to $44 \mathrm{DAT}$ period in 2014 and 2015 was 21 and $20 \mathrm{C}$. The mean air temperature from 45 to 75 DAT was 22.0 and 21.9 C in 2014 and 2015, respectively. Thus, fertilizer N offtake from the Duration-brand coated fertilizers; Ctd U1, Ctd U2, and Ctd U3, showed little correlation to the mean air temperature over the first 11 weeks of the experimental period (Figure 1).

Fertilizer $\mathrm{N}$ offtake from plots treated by coated fertilizer at the $87.8 \mathrm{~kg} \mathrm{~N} \cdot \mathrm{ha}^{-1}$ rate were similarly elevated between 52 and 67 DAT and ranged from 4.9 to $7.6 \mathrm{~kg} \cdot \mathrm{ha}^{-1}$ (Figure 1). Fertilizer $\mathrm{N}$ offtake by the Kentucky bluegrass generally declined over the remaining experimental period. The $\mathrm{Ctd} \mathrm{U} 3$ and $\mathrm{Ctd} \mathrm{U} 4$ fertilizer treatments comprised the highest statistical grouping for fertilizer $\mathrm{N}$ offtake from 75 to $130 \mathrm{DAT}$, with the exception of $\mathrm{N}$ offtake from the Ctd U4 treatment (Polyon) significantly exceeded that of the Ctd U3 treatment (Duration 120) on the 119 DAT sample date (Figure 1).

\subsection{Canopy Characteristics}

Kentucky bluegrass canopy dark green color and canopy density were significantly influenced by the main effect of treatment (Table 2). All fertilizer treatments fostered significantly higher experiment-wide DGCI and NDVI means than the alternative. Fertilizer treatments supplying $43.9 \mathrm{~kg} \mathrm{~N} \cdot \mathrm{ha}^{-1}$ fostered statistically equivalent mean DGCI and NDVI indices. Likewise, treatments supplying $87.8 \mathrm{~kg} \mathrm{~N} \cdot \mathrm{ha}^{-1}$ fostered statistically equivalent mean DGCI and NDVI indices (Table 2).

Regarding DGCI, all $87.8 \mathrm{~kg} \mathrm{~N} \cdot \mathrm{ha}^{-1}$ treatments fostered an experiment-wide mean significantly exceeding that of either fertilizer treatment delivering $43.9 \mathrm{~kg} \mathrm{~N} \cdot \mathrm{ha}^{-1}$, with the exception of the statistically equivalent DGCI for the Ctd U1 and Ctd U2 treatments (Table 2). Regarding NDVI, all $87.8 \mathrm{~kg} \mathrm{~N} \cdot \mathrm{ha}^{-1}$ treatments fostered an experiment-wide mean significantly exceeding that of the conventional urea fertilizer treatment $\left(43.9 \mathrm{~kg} \mathrm{~N} \cdot \mathrm{ha}^{-1}\right)$, with 
the exception of the Ctd U2 treatment (Duration 90). The only $87.8 \mathrm{~kg} \mathrm{~N} \cdot \mathrm{ha}^{-1}$ treatment that fostered a mean NDVI observed to significantly exceed that of the $43.9 \mathrm{~kg} \mathrm{~N} \cdot \mathrm{ha}^{-1} \mathrm{Ctd}$ U1 fertilizer treatment was the Ctd U3 fertilizer (Duration 120).

Canopy dark green color was significantly influenced by DAT and showed a generally increasing response from 0 to $82 \mathrm{DAT}$, with the exception of the control and urea-treated plots 25 to 50 DAT (Figure 2). Canopy DGCI observed of the unfertilized control plots resided within the lowest statistical grouping (Figure 1). This was not surprising, given Kentucky bluegrass has a monthly $\mathrm{N}$ requirement of 20 to $40 \mathrm{~kg} \cdot \mathrm{ha}^{-1}$ [1] and $\mathrm{N}$ is an irreplaceable prerequisite to chlorophyll synthesis [47]. From 45 to 115 DAT, canopy DGCI response to the $87.8 \mathrm{~kg} \cdot \mathrm{ha}^{-1} \mathrm{~N}$ fertilizer treatments significantly exceeded the urea treatment mean DGCI (Figure 2).

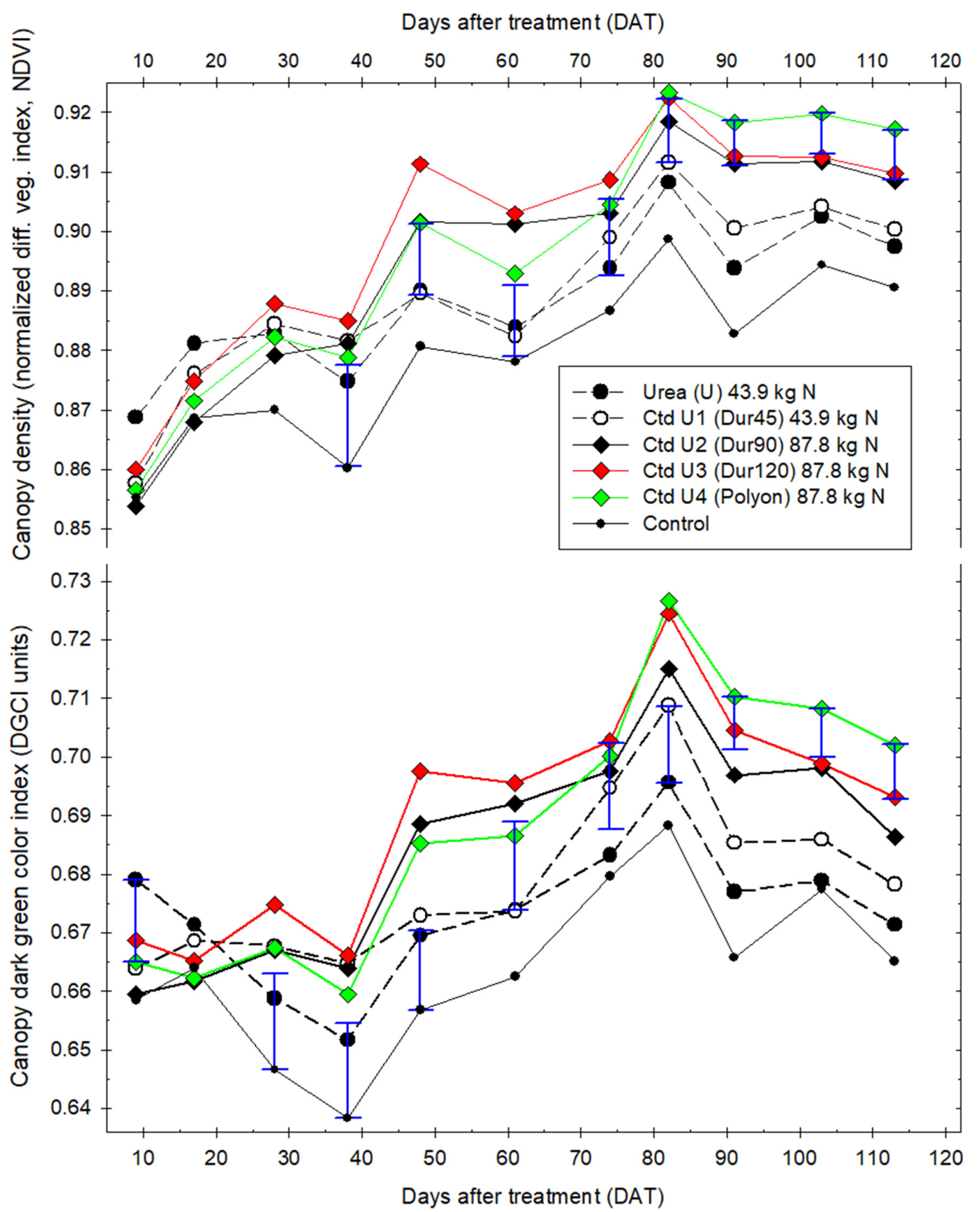

Figure 2. Kentucky bluegrass canopy dark green color index (DGCI) and density (normalized diff. veg. index, NDVI) by fertilizer treatment $\left(\mathrm{ha}^{-1}\right)$ and days after treatment (DAT). Blue error bar lengths denote Fisher's Protected Least Significant Difference (LSD) at a 0.05 alpha level. 
The same was not necessarily true of the Duration 45 treatment, despite sharing an equivalent N delivery rate as urea. The DGCI of the Duration 45 treatment was notably elevated, relative to the other coated fertilizer treatments, 70 to 85 DAT (Figure 2). From 85 to 115 DAT, DGCI of all Kentucky bluegrass plots showed a declining trend but remained greater than DGCI observed in the 0 to 40 DAT experimental period (Figure 2).

Canopy density, as NDVI, was significantly influenced by DAT and observed to follow a generally increasing trend. The NDVI vegetative parameter was also influenced by an interaction between fertilizer treatment and sample DAT (Table 2) manifesting primarily 30+ DAT (Figure 2). For example, all Kentucky bluegrass receiving fertilizer treatment resided in the highest statistical grouping for NDVI 36 DAT. Yet 48 to 61 DAT, only plots treated by coated fertilizers at the $87.8 \mathrm{~kg} \cdot \mathrm{ha}^{-1} \mathrm{~N}$ rate showed significantly denser canopies than the control plots (Figure 2). From 70 to 115 DAT, canopy density response to Duration 90 treatment was intermediate to the other $87.8 \mathrm{~kg} \cdot \mathrm{ha}^{-1} \mathrm{~N}$ treatments (Duration 120 and Polyon coated fertilizers) and plots receiving $43.9 \mathrm{~kg} \cdot \mathrm{ha}^{-1} \mathrm{~N}$ treatments (Figure 2).

\subsection{Monthly Percent Fertillizer N Recovery}

Evaluating the seasonal time array of fertilizer $\mathrm{N}$ assimilation monthly is likely to prove more valuable to practitioners than by the weekly resolution previously depicted (Figure 1). Similarly, reporting the dependent variable as percent fertilizer $\mathrm{N}$ recovery facilitates comparison of several commercial $\mathrm{N}$ fertilizers applied at dissimilar, yet individually commensurate, rates.

Monthly percent fertilizer $\mathrm{N}$ recovery clearly depicts the rapid, yet uncontrolled, release of $\mathrm{N}$ from conventional urea applied at a $43.9 \mathrm{~kg} \mathrm{~N} \cdot \mathrm{ha}^{-1}$ rate (Figure 3). While statistically greatest in the first month following application, subsequent fertilizer $\mathrm{N}$ recovery from granular urea treatment comprised the lowest statistical grouping in Months 2, 3, and 4 (Figure 3).

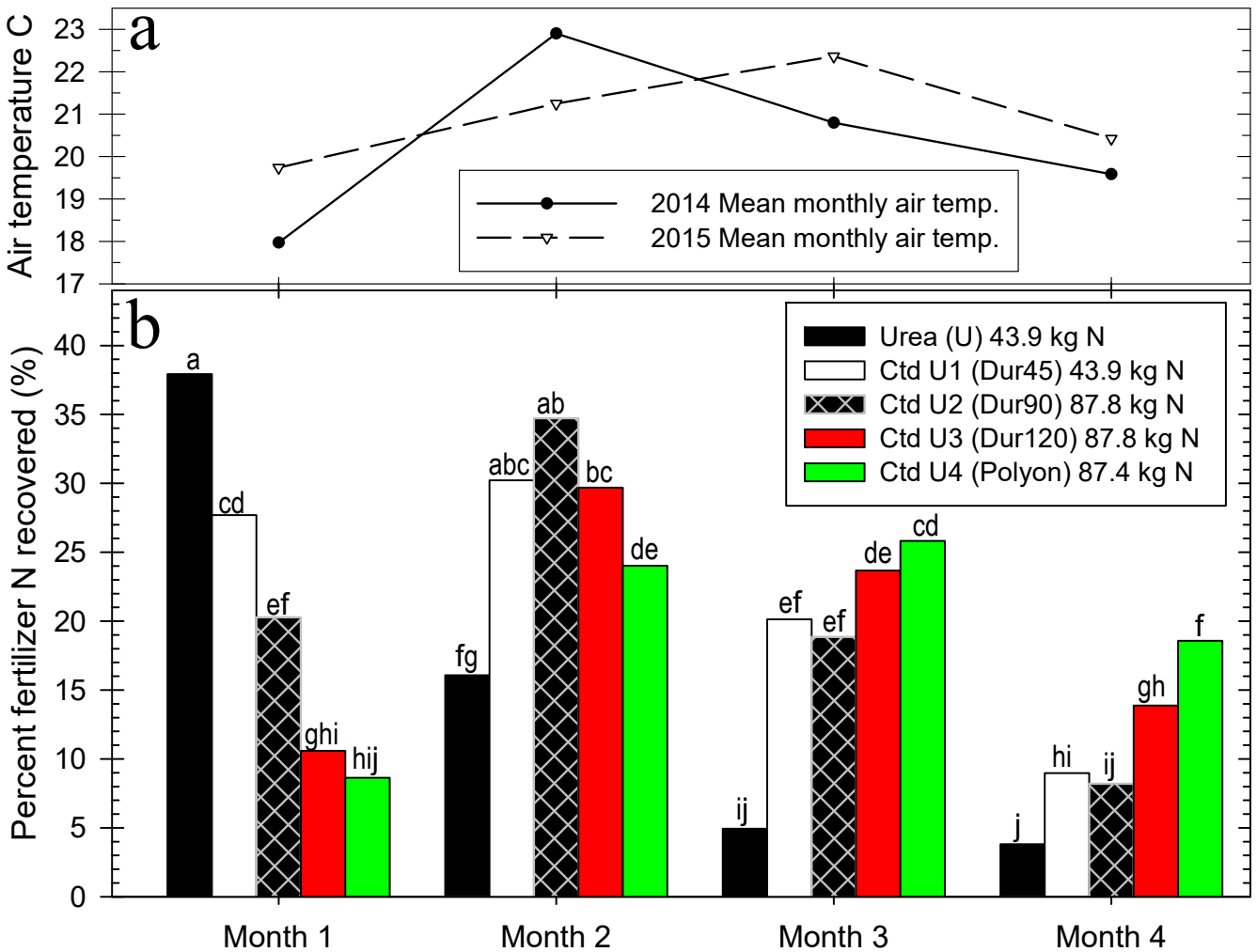

Figure 3. (a) The mean air temperature at experiment site by month from application and year. (b) Percent fertilizer N recovery of Kentucky bluegrass by fertilizer treatment $\left(\mathrm{ha}^{-1}\right.$ ) and month from application. All means denoted by common letters are not significantly different by Fisher's Protected LSD at a 0.05 alpha level. 
Recovery of fertilizer N supplied in the Ctd U1 treatment (Duration 45) was intermediate to the urea treatment and the remaining coated fertilizers in Month 1 . Month 2 recovery of the Ctd U1 treatment fertilizer N, as percent applied, resided in the top statistical grouping and was not significantly different from its recovery in Month 1 (Figure 3). The mean cumulative recovery of the Ctd U1 treatment fertilizer N at the end of Month 2 was 58\%, whereas the mean cumulative recovery of the urea treatment fertilizer N over 2 months was $54 \%$. In Month 3 or 4, recovery of fertilizer N in the Ctd U1 treatment (Duration 45) did not reside in the top statistical grouping but significantly exceeded that of conventional urea (Figure 3).

Cumulative percent fertilizer $\mathrm{N}$ recovery of the conventional urea or Ctd U1 fertilizer treatments was $63 \%$ or $87 \%$, respectively. This percent conventional urea fertilizer $\mathrm{N}$ recovery is similar to the $63 \%$ reported in Kentucky bluegrass clipping offtake collected over the $63-\mathrm{d}$ following a $43.9 \mathrm{~kg} \mathrm{~N} \cdot \mathrm{ha}^{-1}$ application made in July. In the same study, a $43.9 \mathrm{~kg} \mathrm{~N} \cdot \mathrm{ha}^{-1}$ application of a blended urea fertilizer containing 25\% PCU to Kentucky bluegrass, resulted in $66 \%$ fertilizer $\mathrm{N}$ recovery in clipping offtake [21]. Thus, relative to granular urea application, $\geq 25 \%$ fractional PCU inclusion is shown to benefit urea-N recovery by turfgrass.

Recovery of Ctd U2 (Duration 90) fertilizer $\mathrm{N}$ was intermediate among the coated fertilizers in Months 1 and 3 and greatest in Month 2, yet not dissimilar from conventional urea in Month 4 (Figure 3). Likewise, and over the final 3 months of the experimental period, mean recovery of Ctd U2 (Duration 90) fertilizer $N$ on a percent basis (62\%) was statistically equivalent to the 59\% recovered of Ctd U1 (Duration 45). Notwithstanding the disparate rate of application and over the experimental period spanning Months 2 through 4, cumulative fertilizer $\mathrm{N}$ offtake of the Ctd U2 (Duration 90) fertilizer N by Kentucky bluegrass exceeded $54 \mathrm{~kg} \mathrm{~N} \cdot \mathrm{ha}^{-1}$, whereas that of the Ctd U1 (Duration 45) fertilizer N equaled $26 \mathrm{~kg} \mathrm{~N} \cdot \mathrm{ha}^{-1}$ (Figure 3).

Subtle differences in monthly percent fertilizer $\mathrm{N}$ recovery by the Ctd U3 and Ctd U4 fertilizer treatments were observed. Recovery of fertilizer $\mathrm{N}$ by Kentucky bluegrass treated with Ctd U3 (Duration 120) or Ctd U4 (Polyon) were statistically equal in Months 1 and 3 (Figure 3). In Month 2, recovery of Ctd U3 (Duration 120) fertilizer N resided in the highest statistical grouping and significantly exceeded that of Ctd U4 (Polyon). Dissimilar results were observed in Month 4, when recovery of Ctd U4 (Polyon) fertilizer N significantly exceeded all other fertilizer treatments (Figure 3). Cumulative percent fertilizer $\mathrm{N}$ recovery of the Ctd U2, Ctd U3, or Ctd U4 fertilizer treatment, each applied in mid-May at an approximate rate of $87.8 \mathrm{~kg} \mathrm{~N} \cdot \mathrm{ha}^{-1}$, was 82,78 , or $77 \%$, respectively.

\subsection{Unaccounted Fertillizer N}

The fate of nitrogen in fertilizers applied to turfgrass is the subject of great horticultural interest. Extraordinary field research effort has been applied to accounting the mass balance and fate of applied fertilizer $\mathrm{N}$ [48-51]. While the research described herein directly quantified only assimilation and vegetative investment of fertilizer $\mathrm{N}$ via offtake, indirect inference of the conjugate may afford the reader greater appreciation for the treatment array employed. Following 18 weeks of recovery effort in two successive growing seasons, paired-sample t-tests showed that the mean unaccounted fertilizer $\mathrm{N}$ associated with the $43.9 \mathrm{~kg} \mathrm{~N} \cdot \mathrm{ha}^{-1}$ conventional urea treatment did not significantly differ from that of any $87.8 \mathrm{~kg} \mathrm{~N} \cdot \mathrm{ha}^{-1}$ granular PCU treatments at every alpha level $<0.7$. On the other hand, unaccounted fertilizer $\mathrm{N}$ associated with the $43.9 \mathrm{~kg} \mathrm{~N} \cdot \mathrm{ha}^{-1} \mathrm{Ctd} \mathrm{U} 1$ (Duration 45) treatment was significantly less (alpha $=0.05)$ than that resulting from equal application of urea or all described $87.8 \mathrm{~kg} \mathrm{~N} \cdot \mathrm{ha}^{-1}$ granular PCU treatments.

\section{Discussion}

The described research provides useful insight into the field performance of currentlyavailable granular PCU fertilizers as well as opportunity for their practical utilization by 
turfgrass managers. The results confirm the capability of a single, $100 \%$ polymer coated urea fertilizer application to support four or more months of turfgrass $\mathrm{N}$ requirements.

Numerous published works crowned by this same conclusion feature seemingly excessive $\mathrm{N}$ fertilizer application(s) by today's standards. Some describe employing ordinal proxies of $\mathrm{N}$ recovery while others directly measured gaseous and/or other losses before presuming plant recovery of the conjugate. All are merited, yet further complimented by experiments directly measuring fertilizer $\mathrm{N}$ recovery by turfgrass as well as loss by as many pathways as feasible.

Ideally this research confers value in physically sampling, quantifying, and chemicallyanalyzing turfgrass vegetation for the direct affirmation of controlled release and temporal availability of fertilizer nutrients, such as $\mathrm{N}$. While frequent and duplicate sampling by multispectral radiometer facilitated rapid and multi-operator compatible measures of canopy characteristics as continuous ratio data, NDVI and DGCI did not distinguish treatment differences in Kentucky bluegrass response with as great of resolution as fertilizer $\mathrm{N}$ offtake determinations.

A more significant finding of the described field research may be that 18-weeks following a single $87.8 \mathrm{~kg} \mathrm{~N} \cdot \mathrm{ha}^{-1}$ application of the described $100 \%$ PCU fertilizer treatments, the resulting quantity of unaccounted fertilizer- $\mathrm{N}$ was statistically equivalent to that resulting from a $43.9 \mathrm{~kg} \mathrm{~N} \cdot \mathrm{ha}^{-1}$ application of conventional urea. While this $\sim 20 \mathrm{~kg} \mathrm{~N} \cdot \mathrm{ha}^{-1}$ unknown fate outcome remains inordinately undue, and something plant scientists seek to lessen through improved cultural practice, it feasibly comprises an overestimation of loss. For example, $>22 \mathrm{~d}$ of frost-free growing conditions were realized in October 2014 and 2015. Thus, further assimilation of the unaccounted PCU-N fractions by Kentucky bluegrass may have followed termination of each experiment.

\section{Conclusions}

Greater plant recovery of urea-N via polymer-coated CRF use is a realized benefit of ongoing technological refinement by fertilizer manufacturers. While different granular CRFs sharing a common $100 \%$ polymer-coated urea (PCU) attribute may support statistically equivalent cumulative recovery by Kentucky bluegrass or similar turfgrass species, significantly varied patterns of $\mathrm{N}$ release were shown to manifest over an 18-week period.

Future research and modeling efforts identifying and describing repeatable N-release patterns of commercially available CRFs over $>18$-week periods will likely support efficient management and ongoing environmental stewardship by turfgrass professionals. Under conditions identical to those described herein, a single $87.8 \mathrm{~kg} \mathrm{~N} \cdot \mathrm{ha}^{-1}$ application of the $100 \%$ PCU fertilizer treatments described poses no greater environmental risk than conventional urea applied at a $43.9 \mathrm{~kg} \mathrm{~N} \cdot \mathrm{ha}^{-1}$ rate.

Funding: This research was funded by the USDA National Institute of Food and Agriculture, Federal Appropriations under Project PEN04749 and Accession number 1023224; Koch Agronomic Services, LLC; and the Pennsylvania Turfgrass Council.

Institutional Review Board Statement: Not applicable.

Informed Consent Statement: Not applicable.

Data Availability Statement: The datasets are available from the corresponding author on request.

Acknowledgments: The author expresses sincere gratitude to George Fitch and Christopher Pelczar for their assistance in data collection and sample processing.

Conflicts of Interest: The author declares no conflict of interest. The funders had no role in the design of the study; in the collection, analyses, or interpretation of data; in the writing of the manuscript, or in the decision to publish the results. 


\section{References}

1. Carrow, R.N.; Waddington, D.V.; Rieke, P.E. Turfgrass Soil Fertility and Chemical Problems: Assessment and Management; John Wiley \& Sons, Inc: Hoboken, NJ, USA, 2001.

2. Skogley, C.R.; King, J.W. Controlled release nitrogen fertilization of turfgrass. Agron. J. 1968, 60, 61-64. [CrossRef]

3. Boulin, G.M.; Rindt, D.W.; Moore, O.E. Sulfur-coated fertilizers for controlled release. Pilot-plant production. J. Agric. Food Chem. 1971, 19, 801-808. [CrossRef]

4. Rindt, D.W.; Blouin, G.M.; Getsinger, J.G. Sulfur coating on nitrogen fertilizer to reduce dissolution rate. J. Agric. Food Chem. 1968, 16, 773-778. [CrossRef]

5. Allen, S.E.; Hunt, C.M.; Terman, G.L. Nitrogen release from sulfur coated urea as affected by coating weight placement and temperature. Agron. J. 1971, 63, 529. [CrossRef]

6. Volk, G.M.; Horn, G.C. Response curves of various turfgrasses to application of several controlled release nitrogen sources. Agron. J. 1975, 67, 201. [CrossRef]

7. Detrick, J.H. Process for Producing Improved Sulfur-Coated Urea Slow Release Fertilizers. U.S. Patent No. 5,599,374, 2 February 1997.

8. Carrow, R.N. Turfgrass response to slow-release nitrogen fertilizers. Agron. J. 1997, 89, 491-496. [CrossRef]

9. Shaviv, A.; Raban, S.; Zaidel, E. Modeling controlled nutrient release from a population of polymer coated fertilizers: Statistically based model for diffusion release. Environ. Sci. Technol. 2003, 37, 2257-2261. [CrossRef]

10. Medina, L.; Sartain, J.B.; Obreza, T.A.; Hall, W.L.; Thiex, N.J. Optimization and validation of an accelerated laboratory extraction method to estimate nitrogen release patterns of slow- and controlled-release fertilizers. J. AOAC Int. 2014, 97, 661-676. [CrossRef]

11. Azeem, B.; KuShaari, K.; Man, Z.B.; Basit, A.; Tranh, T.H. Review on materials \& methods to produce controlled release coated urea fertilizer. J. Con. Rel. 2014, 181, 11-21. [CrossRef]

12. Davidson, D.; Gu, F.X. Materials for sustained and controlled release of nutrients and molecules to support plant growth. J. Agric. Food Chem. 2012, 60, 870-876. [CrossRef]

13. Liu, M.; Liang, R.; Zhan, F.; Liu, Z.; Niu, A. Preparation of superabsorbent slow release nitrogen fertilizer by inverse suspension polymerization. Polym. Int. 2007, 56, 729-737. [CrossRef]

14. Guo, M.; Liu, M.; Zan, F.; Wu, L. Preparation and properties of a slow-release membrane-encapsulated urea fertilizer with superabsorbent and moisture preservation. Ind. Eng. Chem. Res. 2005, 44, 4206-4211. [CrossRef]

15. Liang, R.; Liu, M.; Wu, L. Controlled release NPK compound fertilizer with the function of water retention. React. Funct. Polym. 2007, 67, 769-779. [CrossRef]

16. $\mathrm{Wu}, \mathrm{L} . ; \mathrm{Liu}, \mathrm{M}$. Preparation and properties of chitosan-coated NPK compound fertilizer with controlled-release and waterretention. Carbohydr. Polym. 2008, 72, 240-247. [CrossRef]

17. Adams, C.; Frantz, J.; Bugbee, B. Macro- and micronutrient-release characteristics of three polymer-coated fertilizers: Theory and measurements. J. Plant. Nutr. Soil Sci. 2013, 176, 76-88. [CrossRef]

18. Guillard, K.; Kopp, K.L. Nitrogen fertilizer form and associated nitrate leaching from cool-season lawn turf. J. Environ. Qual. 2004, 33, 1822-1827. [CrossRef] [PubMed]

19. Snyder, G.H.; Augustin, B.J.; Davison, J.M. Moisture sensor-controlled irrigation for reducing N leaching in bermudagrass turf. Agron. J. 1984, 76, 964. [CrossRef]

20. Knight, E.C.; Guertal, E.A.; Wood, C.W. Mowing and nitrogen source effects on ammonia volatilization from turfgrass. Crop. Sci. 2007, 47, 1628-1634. [CrossRef]

21. Schlossberg, M.J.; McGraw, B.A.; Sebring, R.L.; Hivner, K.R. Nitrogen recovery and loss from Kentucky bluegrass fertilized by conventional or enhanced-efficiency urea granules. Agronomy 2018, 8, 144. [CrossRef]

22. Braun, R.C.; Bremer, D.J. Nitrous oxide emissions from turfgrass receiving different irrigation amounts and nitrogen fertilizer forms. Crop. Sci. 2018, 58, 1762. [CrossRef]

23. Gillette, K.L.; Qian, Y.; Follett, R.F.; Del Grosso, S. Nitrous oxide emissions from a golf course fairway and rough after application of different nitrogen fertilizers. J. Environ. Qual. 2016, 45, 1788-1795. [CrossRef] [PubMed]

24. Maggiotto, S.R.; Webb, J.A.; Wagner-Riddle, C.; Thurtell, G.W. Nitrous and nitrogen oxide emissions from turfgrass receiving different forms of nitrogen fertilizer. J. Environ. Qual. 2000, 29, 621-630. [CrossRef]

25. LeMonte, J.J.; Jolley, V.D.; Summerhays, J.S.; Terry, R.E.; Hopkins, B.G. Polymer coated urea in turfgrass maintains vigor and mitigates nitrogen's environmental impacts. PLoS ONE 2016, 11, e0146761. [CrossRef] [PubMed]

26. Petrovic, A.M. The fate of nitrogenous fertilizers applied to turfgrass. J. Environ. Qual. 1990, 19, 1-14. [CrossRef]

27. Lindsey, A.J.; Thoms, A.W.; McDaniel, M.D.; Christians, N.E. Evaluation of humic fertilizers applied at full and reduced nitrogen rates on Kentucky bluegrass quality and soil health. Agronomy 2021, 11, 395. [CrossRef]

28. Bigelow, C.A.; Walker, K.S.; Hardebeck, G.A. Single fall applications of coated urea fertilizers produce a high quality Kentucky bluegrass turf. Online. Appl. Turfgrass Sci. 2007. [CrossRef]

29. Gen. Assembly of Penn. Senate Bill No. 251, 2021 Session, The Fertilizer Act. Available online: https://www.legis.state.pa.us/ cfdocs $/$ legis $/$ PN / Public/btCheck.cfm?txtType=PDF\&sess Yr=2021\&sessInd=0\&billBody=S\&billTyp=B\&billNbr=0251\&pn=11 83 (accessed on 14 February 2022). 
30. Holst, G.J.; Thygesen, M.; Pedersen, C.B.; Peel, R.G.; Barndt, J.; Christiensen, J.H.; Bonlokke, J.; Hertel, O.; Sigsgaard, T. Atmospheric ammonia, ammonium and incident asthma-A nationwide case-control study in Danish preschool children. Eur. Respir. J. 2017, 50, OA502. [CrossRef]

31. Luchibia, A.O.; Suter, H.; Lam, S.K.; Menhenett, L.; He, J.Z. Temporal response of ureolytic and ammonia-oxidizing microbes and pasture yield to urea and NBPT at Leigh Creek of Victoria in Australia. Appl. Soil Ecol. 2021, 164, 103922. [CrossRef]

32. Dennis, R.L.; Schwede, D.B.; Bash, J.O.; Pleim, J.E.; Walker, J.T.; Foley, K.M. Sensitivity of continental United States atmospheric budgets of oxidized and reduced nitrogen to dry deposition parametrizations. Philos. Trans. R. Soc. Lond. B Biol. Sci. 2013, 368, 1621. [CrossRef]

33. Paulot, F.; Jacob, D.J. Hidden cost of U.S. agricultural exports: Particulate matter from ammonia emissions. Environ. Sci. Technol. 2014, 48, 903-908. [CrossRef]

34. Smith, A.P.; Johnson, I.R.; Schwenke, G.; Lam, S.K.; Suter, H.C.; Eckard, R.J. Predicting ammonia volatilization from fertilized pastures used for grazing. Agric. For. Meteorol. 2020, 287, 14. [CrossRef]

35. Stokstad, E. Ammonia pollution from farming may exact hefty health costs. Science 2014, 343, 238. [CrossRef] [PubMed]

36. de Paula, B.V.; Vitto, B.B.; Sete, P.B.; Trapp, T.; Zalamena, J.; de Melo, G.W.B.; Baldi, E.; Toselli, M.; Rozane, D.E.; Brunetto, G. Annual and residual urea nitrogen contribution to the nutrition of peach trees (Prunus persica L.) grown under subtropical climate. Sci. Hortic. 2021, 284, 1-6. [CrossRef]

37. Henning, S.W.; Branham, B.E.; Mulvaney, R.L. Response of turfgrass to urea-based fertilizers formulated to reduce ammonia volatilization and nitrate conversion. Biol. Fertil. Soils 2013, 49, 51-60. [CrossRef]

38. Zhu, Q.; Schlossberg, M.J.; Bryant, R.B. Foliar fertilization-induced injury and recovery of a creeping bentgrass putting green. J. Plant Nutr. 2016, 39, 1589-1596. [CrossRef]

39. Karcher, D.E.; Richardson, M.D. Quantifying turfgrass color using digital image analysis. Crop. Sci. 2003, 43, 943-951. [CrossRef]

40. Baret, F.; Guyot, G. Potentials and limits of vegetation indices for LAI and APAR assessment. Remote Sens. Environ. 1991, 35, 161-173. [CrossRef]

41. Zhu, Q.; Schlossberg, M.J.; Bryant, R.B.; Schmidt, J.P. Creeping bentgrass putting green response to foliar nitrogen fertilization. Agron. J. 2012, 104, 1589-1594. [CrossRef]

42. McIntosh, M.S. Analysis of combined experiments. Agron. J. 1983, 75, 153-155. [CrossRef]

43. DeKlerk, N.H. Repeated warnings re repeated measures. Aust. N. Z. J. Med. 1986, 16, 637-638. [CrossRef]

44. Matthews, J.N.S.; Altman, D.G.; Campbell, M.J.; Royston, P. Analysis of serial measurements in medical research. Br. Med. J. 1990, 300, 230-235. [CrossRef]

45. Piepho, H.P.; Eckl, T. Analysis of series of variety trials with perennial crops. Grass Forage. Sci. 2014, 69, 431-440. [CrossRef]

46. Clewer, A.G.; Scarisbrick, D.H. Practical Statistics and Experimental Design for Plant and Crop Science; Wiley \& Sons: Chichester, UK, 2000.

47. Marschner, P. Mineral Nutrition of Higher Plants, 3rd ed.; Elsevier: San Diego, CA, USA, 2012.

48. Lindsey, A.J.; Thoms, A.W.; McDaniel, M.D.; Christians, N.E. Plant-available soil nitrogen fluxes and turfgrass quality of Kentucky bluegrass fertilized with humic substances. Crop. Sci. 2021, 61, 4416-4424. [CrossRef]

49. Miltner, E.D.; Branham, B.E.; Paul, E.A.; Rieke, P.E. Leaching and mass balance of $15 N$-labeled urea applied to Kentucky bluegrass turf. Crop. Sci. 1996, 36, 1427-1433. [CrossRef]

50. Tassinari, A.; da Silva, L.O.S.; Drescher, G.L.; de Oliveira, R.A.; Baldi, E.; de Melo, G.W.B.; Zalamena, J.; Mayer, N.A.; Giacomini, S.J.; Carranca, C.L.D.F.; et al. Contribution of cover crop residue decomposition to peach tree nitrogen nutrition. J. Soil Sci. Plant Nutr. 2021, 21, 2124-2136. [CrossRef]

51. Frank, K.W.; O'Reilly, K.M.; Crum, J.R.; Calhoun, R.N. The fate of nitrogen applied to a mature Kentucky bluegrass turf. Crop. Sci. 2006, 46, 209-215. [CrossRef] 